\title{
AN EFFICIENT SYNTHESIS OF 2,2'-ARYLMETHYLENE BIS(3-HYDROXY-5,5-DIMETHYL-2-CYCLOHEXENE-1-ONE) DERIVATIVES USING BAKER'S YEAST ${ }^{* *}$
}

\author{
Jahanbakhsh ASHTARIAN, ${ }^{\text {a }}$ Reza HEYDARI, ${ }^{* a}$ Malek-Taher MAGHSOODLOU ${ }^{\mathrm{a}}$ and Afshin YAZDANI-ELAH-ABADI ${ }^{\mathrm{b}}$ \\ ${ }^{a}$ Department of Chemistry, Faculty of Science, University of Sistan and Baluchestan, P. O. Box: 98135-674, Zahedan, Iran \\ ${ }^{\mathrm{b}}$ Department of Biology, Science and Art University, Yazd, Iran
}

A simple and efficient method was developed for the synthesis of 2,2'-arylmethylene dicyclohexane-1,3-dione derivatives via the Knoevenagel-Michael cascade reactions of aromatic aldehydes and 5,5-dimethyl-1,3cyclohexanedione catalyzed by Saccharomyces cerevisae (baker's yeast) as awhole cell biocatalyst at room temperature in aqueous medium. This procedure provides

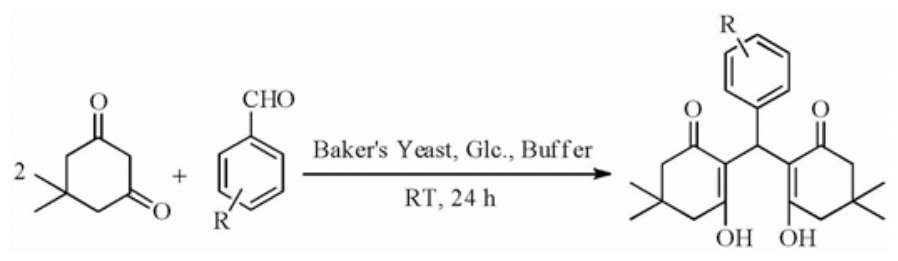
several benefits over the traditional chemical synthesis, such as simple work-up procedure, moderate to excellent yields (80-95\%) and environmental friendliness.

\section{INTRODUCTION}

Organic conversions involving biocatalyst in aqueous medium have received greatattention from researchers. Biocatalyst has the potential to achieve regio- and stereo-specific conversions under mild situations, no side reaction products and can accept unnatural compounds as substrates by reducing the use of hazardous reagents and solvents. Although significant improvement has been made through the use of isolated enzymes, whole-cell biocatalysts with the ability to renew their own respective cofactors are frequently more beneficial. ${ }^{1}$ Moreover, using the whole cell instead of purified enzymes for the reaction is more attractive from economical, environmental, and handling points of view.

Among the various possible biocatalysts, bakers' yeast (Saccharomyces cerevisiae) is a wellknown catalyst due to its low cost, easy-handling, high bioavailability and no requirement for assistance of a professional in microbiology for growth. ${ }^{2}$ Baker's yeast develops better catalytic behavior in aqueous medium and has the ability to accelerate the transformations under mild reaction conditions such as temperature, stirring etc. It has the capacity to catalyze functional group transformations ${ }^{3-6}$ and is known to play a vital role in the synthesis of bioactive compounds such as 2,3-diaryl-4-thiazolidinones, ${ }^{7}$ benzothiazoles, ${ }^{8}$ 3,4dihydropyrimidin-2-(1H)-ones, ${ }^{9}$ 1,4-benzothiazines, ${ }^{10}$ 1,4-dihydropyridines, ${ }^{11}$ indolyl chromenes, ${ }^{12}$ bisindolyl alkanes, ${ }^{12}$ polyhydroquinolines, ${ }^{13}$ isoindolo[2,1a]quinazolines, ${ }^{14} 4 H$-pyranes, ${ }^{15}$ benzimidazoles ${ }^{16}$ and quinoxalines. ${ }^{16}$

Xanthene derivatives are attractive organic compounds with vast applications in pharmacology because of their anti-depressant, antibacterial, antiinflammatory, antifungal, and antimalarial action. ${ }^{17-19}$ They are thrombin inhibitors, and also act as

\footnotetext{
${ }^{*}$ Corresponding author: heydari557@yahoo.com

${ }^{* *}$ Supplementary Information on http:://web.icf.ro/rrch/ or http://revroum.lew.ro
} 
stimulants of the central nervous system. ${ }^{20,21}$ These compounds are potassium channel openers ${ }^{22}$ and have anticancer activity. ${ }^{23}$ Apart from their biological applications, xanthene dyes have been used for diagnostic and imaging applications. ${ }^{24}$ Benzopyran derivatives possess antimicrobial,antiinflammatory, and anti-analgesic properties. ${ }^{25}$ They act as insulin sensitizers. ${ }^{26}$ The compounds having benzopyran rings function as potential potassium channel activators, ${ }^{27}$ and are also active toward postictal contraceptives. ${ }^{28}$

Condensation of aromatic aldehydes with cyclic 1,3-diketones is one of the procedures to synthesize 2,2'-arylmethylenebis (3-hydroxy-2cyclohexene-1-one) and 2,2'-arylmethylenebis (3hydroxy-5,5-dimethyl-2-cyclohexene-1-one). Traditional method for synthesizing these compounds involves the use of piperidine as catalyst. ${ }^{29}$ This method has a main drawback i.e, piperidine cannot be reused. Synthesis of 2,2'-arylmethylenebis (3hydroxy-2-cyclohexene-1-one) and 2,2'-arylmethylenebis (3-hydroxy-5,5-dimethyl-2-cyclohexene-1one) derivatives have been described using $\mathrm{NaOH}$ under high intensity ultrasound radiation ${ }^{30}$ and urea under ultrasound radiation. ${ }^{31}$ These procedures may not be appropriate for large scale production, and furthermore the catalysts cannot be recycled. Several homogeneous catalysts such as $\mathrm{SmCl}_{3}$, $\mathrm{ZnCl}_{2}$, SDS, CsF, ethylenediamine diacetate (EDDA) and heterogeneous catalysts like $\mathrm{ZnO}$, $\mathrm{FeCl}_{3} \cdot 6 \mathrm{H}_{2} \mathrm{O} / \mathrm{TMSCl} /[\mathrm{bmim}]\left[\mathrm{BF}_{4}\right], \mathrm{Yb}(\mathrm{OTf})_{3}-\mathrm{SiO}_{2}$, $\mathrm{HClO}_{4}-\mathrm{SiO}_{2}$ and $L$-lysine have been reported by various chemists. ${ }^{32-40}$ However, many of these catalysts are expensive, require poisonous solvents, cannot be reused and require prolonged reaction time.

We report a novel method for the synthesis of 2,2'-arylmethylene dicyclohexane-1,3-dione derivatives using activated Baker's Yeast asa whole cell biocatalyst at room temperature in aqueous media (Scheme 1).

\section{EXPERIMENTAL}

\section{General}

All chemicals were purchased from Merck, Aldrich and Fluka Chemical Companies and used without further purification. The known products were identified by comparison of their melting points and spectral data with those reported in the literature. Progress of the reactions was monitored by TLC using silica gel SILG/UV 254 plates with ethyl acetate/hexane solutions as the mobile phase. Melting points were recorded on an Electrothermal 9100 melting point apparatus and are not corrected. IR Spectra were recorded on a Bruker Alpha 400-4000 $\mathrm{cm}^{-1}$ spectrophotometer using $\mathrm{KBr}$. ${ }^{1} \mathrm{H}$ NMR spectra were obtained on Bruker Avance III $300 \mathrm{MHz}$ instruments with $\mathrm{CDCl}_{3}$ and DMSO as solvent, and the chemical shifts expressed in $\delta$ units with TMS as the internal standard. ${ }^{13} \mathrm{C}$ NMR was recorded on Bruker Avance III $300 \mathrm{MHZ}$ using $\mathrm{CDCl}_{3}$ as internal standard. Mass spectra were recorded on a AB SCIEX 3200 QTRAP mass spectrometer operating at an ionization potential of $70 \mathrm{eV}$.

General procedure for the synthesis of 2,2'arylmethylenebis(3-hydroxy-5,5-dimethyl-2-cyclohexene-1one) derivatives

Bakers' yeast $(200 \mathrm{mg})$ and D-glucose $(300 \mathrm{mg}$ ) were added in $5 \mathrm{ml}$ phosphate buffer $(\mathrm{pH} \mathrm{7.0)}$ and the resulting solution was stirred overnight at room temperature for fermentation. Dimedone (280 mg, $2 \mathrm{mmol}$ ), benzaldehyde derivatives $(1 \mathrm{mmol})$ were added to the fermenting yeast and the reaction mixture was stirred for further $24 \mathrm{hs}$. The progress of the reaction was monitored by thin layer chromatography. After completion of the reaction, it was extracted with dichloromethane and finally dried over anhydrous sodium sulphate. The organic layer was concentrated in vacuo to give crude product. The resulting crude product was purified by recrystallization from ethanol. The pure 2,2'arylmethylenebis(3-hydroxy-5,5-dimethyl-2-cyclohexene-1one) derivatives were obtained. The products were fully characterized by IR, ${ }^{1} \mathrm{HNMR},{ }^{13} \mathrm{CNMR}$ and mass spectroscopy and also by comparison of their physical and spectral data with that reported.<smiles>[R]c1ccc(C=O)cc1</smiles>

$\mathrm{R}=\mathrm{H}, 4-\mathrm{Br}, 2-\mathrm{Cl}, 4-\mathrm{Cl}, 4-\mathrm{F}, 4-\mathrm{OH}, 4-\mathrm{OCH}_{3}, 2-\mathrm{NO}_{2}, 3-\mathrm{NO}_{2}, 4-\mathrm{NO}_{2}, 2,4-(\mathrm{Cl})_{2}, 2,4-(\mathrm{OH})_{2}, 3,4-\left(\mathrm{OCH}_{3}\right)_{2}$

Scheme 1 - Synthesis of 2,2'-arylmethylenebis(3-hydroxy-5,5-dimethyl-2-cyclohexene-1-one) derivatives. 
2,2'-(4-Flurophenyl)methylenebis(3-hydroxy-5,5-dimethyl-2cyclohexene-1-one) (3e):

IR $(\mathrm{KBr}) / v\left(\mathrm{~cm}^{-1}\right): 3856,3049,2963,2932,2874,2635$, $1882,1593,1505,1496,1451,1419,1373,1249,1159,1094$, $1015,930,870,799,695,632,576,505,460 ;{ }^{1} \mathrm{H}$ NMR $(300$ $\left.\mathrm{MHz}, \mathrm{CDCl}_{3}\right): \delta 11.92(\mathrm{~s}, 1 \mathrm{H}, \mathrm{OH}), 11.35(\mathrm{~m}, 1 \mathrm{H}, \mathrm{OH}), 7.29$ (s, 2H, Ar-H), 6.94-7.09 (m, 2H, Ar-H), $5.50(\mathrm{~s}, 1 \mathrm{H}, \mathrm{CH})$, 2.36-2.45 (m, $\left.8 \mathrm{H}, 4 \mathrm{CH}_{2}\right), 1,24\left(\mathrm{~s}, 6 \mathrm{H}, 2 \mathrm{CH}_{3}\right), 1.12(\mathrm{~s}, 6 \mathrm{H}$, $\left.2 \mathrm{CH}_{3}\right) ; \mathrm{m} / z$ (ESI): $387\left[\mathrm{M}+\mathrm{H}^{+}\right]$.

\section{2,2'-(2,4-Dihydroxyphenyl)methylenebis(3-hydroxy-5,5-} dimethyl-2-cyclohexene-1-one) (3I):

IR $(\mathrm{KBr}) / v\left(\mathrm{~cm}^{-1}\right): 3190,2957,2881,2816,1879,1623$, $1588,1514,1462,1389,1305,1231,1148,1076,1014,944$, 855, 814, 747, 664, 599, 508, 428; ${ }^{1} \mathrm{HNMR}(300 \mathrm{MHz}$, DMSO): $\delta 10.31(\mathrm{~s}, 1 \mathrm{H}, \mathrm{OH}), 9.14(\mathrm{~m}, 1 \mathrm{H}, \mathrm{OH}), 6.74-6.77(\mathrm{~d}$, 1H, Ar-H), 6.41-6.45 (m, 1H, Ar-H), $6.32(\mathrm{~d}, 1 \mathrm{H}, \mathrm{Ar}-\mathrm{H}), 4.94$ (s, $1 \mathrm{H}, \mathrm{CH}), 2.01-2.55\left(\mathrm{~m}, 8 \mathrm{H}, 4 \mathrm{CH}_{2}\right), 1,05\left(\mathrm{~s}, 3 \mathrm{H}, \mathrm{CH}_{3}\right), 0.98$ $\left(\mathrm{s}, 3 \mathrm{H}, \mathrm{CH}_{3}\right), 0.90\left(\mathrm{~s}, 6 \mathrm{H}, 2 \mathrm{CH}_{3}\right) ;{ }^{13} \mathrm{C} \mathrm{NMR}(75 \mathrm{MHz}$, DMSO): $\delta$ 26.69, 28.16, 29.66, 32.06, 41.15,50.91, 102.32, $111.62,129.25,150.50,156.56,165.12,196.36 ; \mathrm{m} / \mathrm{z}(\mathrm{ESI})$ $406.4\left[\mathrm{M}+\mathrm{H}^{+}\right]$.

\section{2,2'-(3,4-Dimethoxyphenyl)methylenebis(3-hydroxy-5,5- dimethyl-2-cyclohexene-1-one) (3m):}

IR $(\mathrm{KBr}) / v\left(\mathrm{~cm}^{-1}\right): 3730,3076,3009,2962,2932,2876$, 2834, 1909, 1589, 1515, 1462, 1416, 1374, 1305, 1240, 1148, $1027,869,826,761,663,575,532,458 ;{ }^{1} \mathrm{H}$ NMR $(300 \mathrm{MHz}$, DMSO): $\delta 10.31$ (brs, $1 \mathrm{H}, \mathrm{OH}), 9.41(\mathrm{~s}, 1 \mathrm{H}, \mathrm{OH}), 6.43-6.77$ (d, 1H, Ar-H), 6.41-6.45 (m, 1H, Ar-H), 6.32 (d, 1H, Ar-H), $4.94(\mathrm{~s}, 1 \mathrm{H}, \mathrm{CH}), 2.00-2.55\left(\mathrm{~m}, 8 \mathrm{H}, 4 \mathrm{CH}_{2}\right), 1,05\left(\mathrm{~s}, 3 \mathrm{H}, \mathrm{CH}_{3}\right)$, $0.98\left(\mathrm{~s}, 3 \mathrm{H}, \mathrm{CH}_{3}\right), 0.90\left(\mathrm{~s}, 6 \mathrm{H}, 2 \mathrm{CH}_{3}\right) ;{ }^{13} \mathrm{C} \mathrm{NMR}(75 \mathrm{MHz}$, DMSO): $\delta$ 28.24, 30.96, 31.74, 47.03, 55.61, 100.76, 111.04, $115.18,133.57,146.88,187.92$.

\section{RESULTS AND DISCUSSION}

Herein, we report an efficient and economical protocol for the synthesis of 2,2'-arylmethylene dicyclohexane-1,3-dione derivatives catalyzed by baker's yeast as a whole cell biocatalyst at room temperature in aqueous media.

To find the best experimental conditions we started the investigations by performing one-pot three-component synthesis of 2,2'-((4-nitrophenyl)methylene)bis(3-hydroxy-5,5-dimethylcyclohex-2-enone) (3j) by allowing the cyclocondensation of dimedone (1) and 4-nitrobenzaldehyde (2j) using baker's yeast as biocatalyst considering this reaction as a model.

We carried out the control experiment to examine the catalytical proficiency of active baker's yeast at different reaction conditions. The model reaction was performed in the absence of baker's yeast in aqueous media and we noticed that after workup and purification, $30 \%$ of 2,2'-((4nitrophenyl)methylene)bis(3-hydroxy-5,5-dimethylcyclohex-2-enone) (3j) was obtained. This reaction was also run by employing inactivated baker's yeast (inactivation was carried out by boiling yeast in water) as a catalyst but we did not find the formation of the desired product. These results indicate that baker's yeast is necessary to catalyze the reaction. Based upon the results obtained, it was confirmed that the presence of fermented baker's yeast was essential for successful Michael addition of dimedone to substituted benzaldehydes.

The encouraging results gained in the preliminary experiments provoked us to explore the generalization of this protocol tovarious other substituted benzaldehydes 2a-m and dimedone. A variety of aldehydes containing electron-donating and electron-withdrawing groups were successfully employed to prepare corresponding 2,2'arylmethylenebis(3-hydroxy-5,5-dimethyl-2-cyclohexene-1-one) derivatives. The reaction showed good functional group tolerancefor example, substituents like $\mathrm{Br}, \mathrm{Cl}, \mathrm{F}, \mathrm{OH}, \mathrm{OCH}_{3}$, and $\mathrm{NO}_{2}$ present on the aryl ring of the aldehyde were well tolerated (entries 2-10, Table 1). The aldehydes containing more than one substituentsor bulky aromatic ring for example, (entries 11-13, Table 1) were also well tolerated providing excellentyields of the corresponding products. Both activated and less reactive aromatic aldehydes participated well in the present condensation reaction affording the expected products in high yields and no significant substituent effect was observed on the yields of the products.

Baker's yeast produces variety of enzymes during fermentation. ${ }^{41,42}$ Amongst them, lipase is recognized to catalyze organic conversions. ${ }^{11}$ It is known that lipases are effective proteins having amino acid residues with diverse functionalities at particular locations. These amino acid residues like histidine, serine and aspartate or glutamate are known to form hydrogen bonding with oxygen hence increasing the electrophilicity of atom attached to oxygen. ${ }^{11,12}$ In our case, amino hydrogen of histidine is likely to be responsible for enhancing electrophilicity of aldehydic carbon forming hydrogen bonding with carbonyl oxygen, thereby accelerating the rate of addition of dimedone to aldehydes as depicted in Scheme 2. Another amino acid remainder, aspartic anion ${ }^{11}$ might be responsible for enhancing nucleophilicity at dimedonecausing its facile addition on the II as depicted in Scheme 2. These factors are probably responsible for the cyclocondensation at room temperature in successive steps forming the desired 2,2'-arylmethylenebis(3-hydroxy-2-cyclohexene-1one) derivatives (Scheme 2). 
Table 1

Synthesis of 2,2'-arylmethylenebis(3-hydroxy-2-cyclohexene-1-one) derivatives 3a-m

\begin{tabular}{|c|c|c|c|c|c|}
\hline \multirow[t]{2}{*}{ Entry } & \multirow[t]{2}{*}{$\mathrm{R}$} & \multirow[t]{2}{*}{ Product } & \multirow[t]{2}{*}{ Yield (\%) } & \multicolumn{2}{|c|}{ Melting point, $\mathrm{C}$} \\
\hline & & & & Found & Reported \\
\hline 1 & $\mathrm{H}$ & $3 \mathbf{a}$ & 95 & $194-196$ & $192-194^{43}$ \\
\hline 2 & $4-\mathrm{Br}$ & $\mathbf{3 b}$ & 80 & $164-166$ & $161-163^{45}$ \\
\hline 3 & $2-\mathrm{Cl}$ & 3c & 94 & $204-206$ & $202-204^{43}$ \\
\hline 4 & $4-\mathrm{Cl}$ & 3d & 95 & $146-148$ & $145-147^{43}$ \\
\hline 5 & $4-F$ & $3 e$ & 95 & $184-186$ & $186-188^{35}$ \\
\hline 6 & $4-\mathrm{OH}$ & $3 f$ & 80 & $192-194$ & $192-194^{43}$ \\
\hline 7 & $4-\mathrm{OCH}_{3}$ & $3 g$ & 90 & $146-148$ & $146-148^{43}$ \\
\hline 8 & $2-\mathrm{NO}_{2}$ & $3 \mathbf{h}$ & 80 & $188-190$ & $188-190^{43}$ \\
\hline 9 & $3-\mathrm{NO}_{2}$ & $3 \mathbf{i}$ & 80 & $192-194$ & $193-195^{43}$ \\
\hline 10 & $4-\mathrm{NO}_{2}$ & $3 \mathbf{j}$ & 95 & $186-188$ & $188-190^{43}$ \\
\hline 11 & $2,4-(\mathrm{Cl})_{2}$ & $3 \mathbf{k}$ & 80 & $190-192$ & $188-189^{44}$ \\
\hline 12 & $2,4-(\mathrm{OH})_{2}$ & 31 & 80 & $233-235$ & - \\
\hline 13 & $3,4-\left(\mathrm{OCH}_{3}\right)_{2}$ & $3 m$ & 95 & $184-186$ & $187-189^{43}$ \\
\hline
\end{tabular}

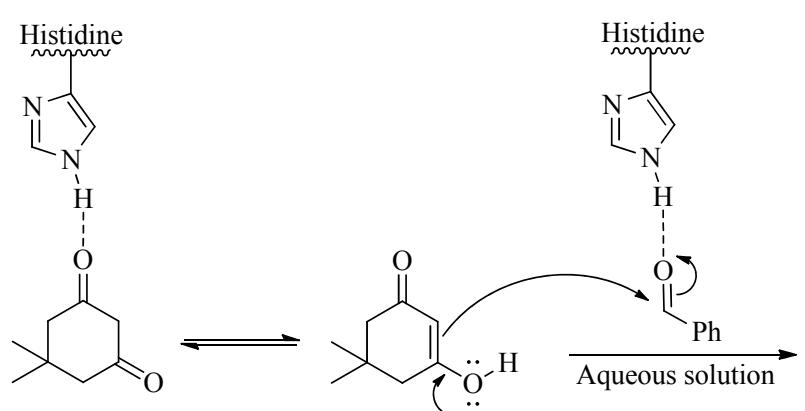

C

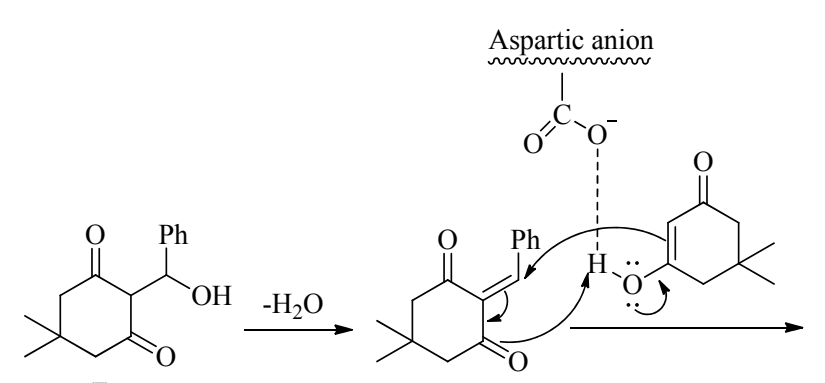

(II)<smiles>CC1(C)CC(=O)C(C(C2=C(O)CC(C)(C)CC2=O)c2ccccc2)C(=O)C1</smiles>

(III)

(IV)

(3)

Scheme 2 - Proposed mechanism for Baker,s Yeast catalyzed synthesis of 2,2'-arylmethylenebis(3-hydroxy-2-cyclohexene-1-one) derivatives.

No product formation was observed by employing thermally deactivated baker's yeast, but with active baker's yeast 3jwas obtained in 95\% yield. Due to thermal inactivation of baker's yeast lipase is inactivated which results in no product formation. It indicates that, components apart from enzymes existing in baker's yeast are not responsible to catalyze the Michael addition of aldehyde to dimedone. Therefore, we believe that the enzyme lipase available in baker's yeast is likely to be responsible to accelerate the 1,4conjugate addition of aldehyde to dimedone.

\section{CONCLUSION}

We have reported for first time the use of baker's yeast as wholecell biocatalyst to accelerate the synthesis of 2,2'-arylmethylenebis(3-hydroxy-5,5- dimethyl-2-cyclohexene-1-one) derivatives from the reaction of aldehydes and dimedone. The biocatalyst is inexpensive, easily available and biodegradablemaking the protocol cost effective and ecofriendly. The procedure does not necessitate the use of any volatile organic solvent, damaging metal catalyst and thus, is a simple, environmentally friendly, and high yielding reaction for the synthesis of 2,2'-arylmethylenebis(3-hydroxy-5,5-dimethyl-2cyclohexene-1-one) derivatives.

Acknowledgment: We gratefully acknowledge financial support from the Research Council of University of Sistan and Baluchestan, Iran.

\section{REFERENCES}

1. B. G. Davis and V. Boyer, Nat. Prod. Rep., 2001, 18, 618-640. 
2. J. B. Jones, Tetrahedron, 1986, 42, 3351-3404.

3. M. Zagozada and J. Plenkiewicz, Tetrahedron: Asymmetry, 2007, 18, 1457.

4. N. Athanasiou, A. J. Smallridge and M. A. Trewhella, J. Mol. Catal. B: Enzym., 2001, 11, 893-896.

5. F. Li, J. Cui, X. Quan and R. Zhang, Chem. Commun., 2004, 2328.

6. M. M. Kostraby, A. J. Smallridge and M. A. Trewhella, Biotech. Bioeng., 2002, 77, 827-831.

7. U. R. Pratap, D. V. Jawale, M. R. Bhosle and R. A. Mane, Tetrahedron Lett., 2011, 52, 1689-1691.

8. U. R. Pratap, J. R. Mali, D. V. Jawale and R. A. Mane, Tetrahedron Lett., 2009, 50,1352-1354.

9. A. Kumar and R. A. Maurya, Tetrahedron Lett., 2007, 48, 4569-4571.

10. U. R. Pratap, D. V. Jawale, B. S. Londhe and R. A. Mane, J. Mol. Catal. B: Enzym., 2011, 68, 94-97.

11. J. H. Lee, Tetrahedron Lett., 2005, 46, 7329-7330.

12. N. G. Singh, R. Nongrum, C. Kathing, J. W. S. Rani and R. Nongkhlaw, Green Chem. Lett. Rev., 2014, 7, 137-144.

13. A. Kumar and R. A. Maurya, Tetrahedron Lett., 2007, 48, 3887-3890.

14. J. R. Avalani, D. S. Patel and D. K. Raval, J. Mol. Catal. B: Enzym., 2013, 90, 70-75.

15. U. R. Pratap, D. V. Jawale, P. D. Netankar and R. A. Mane, Tetrahedron Lett., 2011, 52, 5817-5819.

16. Y. S. Beheshtiha, M. M. Heravi, M. Amrollah, M. Saeedi and A. Fallah, Chem. Sci. Trans., 2012, 1, 134-138.

17. J. P. Poupelin, G. S. Rut, F. Blanpin, G. Narcisse, G. U. Ernouf and R. Lakroix, Eur. J. Med. Chem., 1978, 13, 67-71.

18. J. J. Omolo, M. M. Johnson, S. F. V. Vuuren and C. B. D. Koning, Bioorg. Med. Chem. Lett., 2011, 21, 7085-7088.

19. K. Chibale, M. Visser, D. V. Schalkwyk, P. J. Smith, A. Saravanamuthu and A. H. Fair-lamb, Tetrahedron, 2003, 59, 2289-2296.

20. R. Frédérick, S. Robert, C. Charlier, J. Wouters, B. Masereel and L. Pochet, J. Med. Chem., 2007, 50, 3645-3650.

21. P. D. Re, L. Sagramora, V. Mancini, P. Valenti and L. Cima, J. Med. Chem., 1970, 13, 527-531.

22. R. C. Gadwood, B. V. Kamdar, L. A. C. Dubray, M. L. Wolfe, M. P. Smith, W. Watt, S. A. Mizsak and V. E. Groppi, J. Med. Chem.,1993, 36, 1480-1487.

23. G. W. Rewcastle, G. J. Atwell, L. Za, B. C. Baquley and W. A. J. Denny, Med. Chem., 1991, 34, 217-222.

24. S. A. Hilderbrand and R. Weissleder, Tetrahedron Lett., 2007, 48, 4383-4385.
25. S. M. Hasan, M. M. Alam, A. Husain, S. Khanna, M. Akhtar and M. S. Zaman, Eur. J. Med. Chem., 2009, 44, 4896-4903.

26. L. Tang, J. Yu, Y. Leng, Y. Feng, Y. Yang and R. Ji, Bioorg. Med. Chem. Lett., 2003, 13, 3437-3440.

27. E. Tyrrell, K. H. Tesfa, I. Greenwood and A. Mann, Bioorg. Med. Chem. Lett., 2008, 18, 1237-1240.

28. K. Hajela and R. S. Kapil, Eur. J. Med. Chem., 1997, 32, 35-142.

29. E. C. Horning and M. G. Horning, J. Org. Chem., 1946, 11, 95-99.

30. G. Cravotto, A. Demetri, G. M. Nano, G. Palmisano, A. Penoni and S. Tagliapietra, Eur. J.Org. Chem., 2003, $4438-4444$.

31. J. T. Li, Y. W. Li, Y. L. Song and G. F. Chen, Ultrason. Sonochem., 2012, 19, 1-4.

32. D. H. Jung, Y. R. Lee, S. H. Kim and W. S. Lyoo, Bull. Korean Chem. Soc., 2009, 30, 1989-1995.

33. A. Ilangovan, S. Malayappasamy, S. Muralidharan and S. Maruthamuthu, Chem. Cent. J., 2011, 5, 81-86.

34. L. L. Bin, J. T. Shou, H. L. Sha, L. Meng, Q. Na and L. T. Shuang, Eur. J. Chem., 2006, 3, 117-121.

35. K. P. Nandre, V. S. Patil and S. V. Bhosale, Chin. Chem. Lett., 2011, 22, 777-780.

36. M. T. Maghsoodlou, S. M. H. Khorassani, Z. Shahkarami, N. Maleki and M. Rostamizadeh, Chin. Chem. Lett., 2010, 21, 686-689.

37. V. K. Rao, M. M. Kumar and A. Kumar, Indian J. Chem., 2011, 50B, 1128-1135.

38. X. Fan, L. Sen, Y. Z. Zhang, X. Y. Hu, X. Y. Wang and J. Ji, Chin. J. Org. Chem., 2005, 25, 1482-1486.

39. S. Kantevari, R. Bantu and L. Nagarapu, J. Mol. Catal. A: Chem., 2007, 269, 53-57.

40. Y. Zhang, C. Sun, J. Liang and Z. Shang, Chin. J. Chem., 2010, 28, 2255-2259.

41. R. C. Jones and J. S. Hough, J. Gen. Microbiol., 1970, 60, 107-116.

42. B. Pscheidt and A. Glieder, Microb. Cell Fact, 2008, 7, 25-83.

43. A. Ilangovan, S. Muralidharan, P. Sakthivel, S. Malayappasamy, S. Karuppusamy and M. P. Kaushik, Tetrahedron Lett., 2013, 54, 491-494.

44. J. T. Li, Y. W. Li, Y. L. Song and G. F. Chen, Ultra. Sonochem., 2012, 19, 1-4.

45. M. Bayat, H. Imanieh, S. H. Hossieni, Chin. Chem. Lett., 2009, 20, 656-659. 
